\title{
NURSE ETHICAL DILEMMAS IN INPATIENT WARD OF BALADHIKA HUSADA HOSPITAL JEMBER
}

Siti Amaliatul Khoiroh ${ }^{1 *}$, Ahmad Rifai $^{1}$, Alfid Tri Afandi $^{1}$

Afiliasi

1. Faculty of Nursing, University of Jember

Dikirim 30 Juli 2019

Direvisi 26 Juli 2020

Diterima 4 Agustus 2020

Dipublikasikan 30 November 2020

*Corresponding author

Email :

liaa3526@gmail.com

\begin{abstract}
ABSTRAK
Perawat rawat inap adalah perawat pelaksana yang melakukan tindakan sesuai dengan standar operasional prosedur maupun pencegahan serta mengidentifikasi keadaan lingkungan selama 24 jam. Beban kerja tersebut dapat menyebabkan munculnya sikap yang menjadi keluhan pasien yaitu ketidakstabilan emosi perawat karena kelelahan dan kesibukan yang tinggi. Dampak dari dilema etik yang dialami perawat salah satunya adalah dampak emosional pada perawat seperti timbulnya rasa marah, stress, frustrasi, dan timbul rasa takut pada saat proses pengambilan keputusan. Desain penelitian adalah penelitian kualitatif dengan pendekatan fenomenologi yang bertujuan untuk menggali persepsi dan pengalaman perawat terhadap dilema etik keperawatan diruang rawat inap. Sejumlah enam partisipan terlibat dalam penelitian ini yang dipilih dengan teknik purposive sampling. Partisipan adalah perawat pelaksana diruang rawat inap RS Baladhika Husada Jember. Metode analisa Colaizzi digunakan untuk menarik kesimpulan dalam penelitian ini. Hasil penelitian diperoleh lima tema utama: pengetahuan dan pemahaman perawat, bentuk dilema etis yang dialami oleh perawat, dilema etis yang terkait dengan prinsip-prinsip etika, tindakan ketika mengalami dilema etis dan harapan untuk perawat. Untuk meningkatkan kualitas kinerja perawat, diharapkan bahwa di masa depan perawat di ruang rawat inap diberikan edukasi yang berkelanjutan terkait dilemma etis dalam pelaksanaan asuhan keperawatan professional.
\end{abstract}

Kata kunci : dilema etik, perawat, persepsi, pengalaman

\begin{abstract}
A ward nurse is a practitioner nurse who takes action according to standard operating procedures and prevention and identifies the state of the environment for 24 hours. The workload can lead to the emergence of attitudes that become complaints of patients, namely the emotional instability of nurses because of fatigue and high activity. The impact of ethical dilemmas experienced by nurses, one of which is the emotional impact on nurses such as anger, stress, frustration, and fear during the decision-making process. The research design is qualitative research with a phenomenological approach that aims to explore nurses' perceptions and experiences of the ethical dilemma of nursing in the inpatient ward. A total of six participants involved in this study were selected by purposive sampling technique. Participants were the practitioner nurses in the inpatient ward of the Baladhika Husada Hospital in Jember. Colaizzi analysis method is used to conclude this study. The results obtained by five main themes: nurse knowledge and understanding, forms of ethical dilemmas experienced by nurses, ethical dilemmas related to ethical principles, actions when experiencing ethical dilemmas, and expectations for nurses. Continuing education regarding nurse ethical dilemmas in the implementation of professional nursing care is crucial to improve the quality of nurse performance when delivering nursing care.
\end{abstract}

Keywords : ethical dilemmas, nurses, perception, experience

Sitasi jurnal :

Khoiroh SA, Rifai A, Afandi AT. 2020. Nurse Ethical Dilemmas In Inpatient Ward Of Baladhika Husada Hospital Jember. Jurnal Ilmu Keperawatan 8 (2): 121-128. Doi: 10.21776/ub.jik.2020.008.02.9 


\section{PENDAHULUAN}

Dilema etik merupakan konflik yang sering terjadi dalam praktik keperawatan dan memunculkan banyak tantangan dan dampak pada pemberian pelayanan (Rainer dkk., 2018). Dampak dari dilema etik yang dialami perawat salah satunya adalah dampak emosional pada perawat seperti timbulnya rasa marah, stress, frustrasi, dan timbul rasa takut pada saat proses pengambilan keputusan (Tappen, M.R., 2010). Dilema etik muncul apabila keputusan ditetapkan tanpa mempertimbangkan keputusan yang lain, karena pada dasarnya setiap keputusan memiliki kelebihan dan kekurangan (Ose, 2018). Pada penelitian Oerlemans dkk., (2015) disebutkan salah satu contoh dilema etik yang terjadi pada perawat pada perawat ruang rawat inap yaitu saat terdapat pasien yang kondisinya memburuk atau merasakan kesakitan, dimana sebenarnya perawat mengetahui apa yang harus dilakukan tetapi karena tindakan perawat diruang rawat inap sangat terbatas maka perawat harus menunggu keputusan yang dibuat oleh dokter.

Menurut penelitian Zubović (2018) yang dilakukan di beberapa negara di Primorsko- Gorski, Varazdin, Bjelovar, Zagreb, Karlovac, Sisak, Istria dan Zadar didapatkan hasil bahwa pada prinsip keadilan perawat mengalami dilema etik sebanyak 49\%. Sedangkan berdasarkan penelitian Ito \& Natsume (2015) yang meneliti tentang dilema etik pada empat perawat di Jepang didapatkan hasil bahwa terdapat perawat yang mengalami empat dilema etik yang berkaitan dengan pengisian informed consent, isuisu tentang martabat pasien, kerahasiaan informasi pasien dan isu-isu yang terkait dengan keselamatan pasien dan terdapat perawat yang mengalami sebelas dilema etik yang berkaitan dengan isu-isu tentang martabat atau harga diri pasien, hubungan antara pasien dan keluarga, dokter dan staf, perlindungan informasi pasien, keselamatan pasien, hak pasien, kualitas pelayanan pasien, kerahasiaan, kondisi kerja pribadi, kondisi kerja karyawan dan moral profesional.

Etika merupakan prinsip dasar perilaku suatu individu yang digunakan untuk membuat keputusan etis yang benar sehingga tidak menyebabkan dilema etik pada perawat (Ibrahim Yousif, 2018). Oleh karena itu perawat perlu memahami mengenai prinsipprinsip etis dalam praktik keperawatan yang terdiri dari prinsip otonomi (autonomy), kemanfaatan (beneficience), keadilan (justice), tidak merugikan (non maleficience), kejujuran (veracity), menepati janji (fidelity), karahasiaan (confidentiality), akuntabilitas (accountabiliy) agar tidak menimbulkan dampak seperti strees kerja maupun kelelahan pada perawat saat memberikan pelayanan (Dalami dalam Ose 2018).

Pada penelitian Sari dkk., (2016) disebutkan bahwa perawat rawat inap adalah perawat pelaksana yang melakukan tindakan sesuai dengan standar operasional prosedur maupun pencegahan dari kesalahan atau kejahatan serta mengidentifikasi keadaan lingkungan selama 24 jam yang dapat mengganggu keamanan dan kenyamanan pasien termasuk saat memberikan pelayanan kurang ramah dan kurang perhatian. RS DKT (Djawatan Kesehatan Tentara) merupakan rumah sakit militer pertama yang mendapat penilaian dengan instrumen komisi akreditasi rumah sakit dengan hasil lulus tingkat paripurna. Peran perawat dalam pencapaian ini sangatlah banyak yaitu yang menjadi salah satu instrumen komisi akreditasi rumah sakit dan tentunya menjadi beban tersendiri bagi setiap individu perawat selain tugas pokoknya dalam melakukan pelayanan kesehatan. Rumah Sakit Baladhika Husada Jember adalah rumah sakit militer yang memiliki budaya berbeda yang disiplin dengan pelatihan seperti militer yang tegas dan bertanggung jawab dan juga mempunyai stress kerja yang tinggi dalam mempertahankan akreditasi rumah sakit tersebut (Nafi'ah, 2018). Hasil penelitian Ria Aridya Liarucha 2015 yang dilakukan pada perawat rawat inap RS DKT menyebutkan bahwa perawat mempunyai keluhan mengenai penurunan konsentrasi, lelah seluruh tubuh, lupa, enggan bekerja dengan cekatan, dan daya pikir menurun. Beberapa keluhan yang terjadi mengindikasikan kemungkinan terjadinya kelelahan dan stress kerja perawat. Kondisi tersebut juga mengakibatkan terganggunya proses pemberian layanan keperawatan. Menurut Caldwell at all, 1981, Thelan, 1994 dalam Astuti 2012 sumber stress kerja perawat salah satunya dipengaruhi oleh dilema etik yang dihadapi perawat.

Tujuan dari penelitian ini adalah untuk mengetahui persepsi dan pengalaman perawat terhadap dilema etik keperawatan di ruang rawat inap RS DKT Jember. Penelitian ini bisa dijadikan sumber atau referensi yang berkaitan dengan dilema etik yang 
dialami perawat pada ruang rawat inap, meningkatkan profesionalitas dan kualitas pelayanan keperawatan.

\section{METODE}

Penelitian ini menggunakan metode penelitian kualitatif dengan pendekatan fenomenologis. Teknik pemilihan partisipan pada penelitian ini, peneliti menggunakan teknik purposive sampling. Peneliti mendapatkan sejumlah 6 partisipan dengan kriteria perawat dan kepala ruangan dengan masa kerja lebih dari 5 tahun di ruang rawat inap Rumah Sakit Baladhika Husada (RS DKT) dan partisipan yang bersedia untuk di wawancarai. Teknik penyajian data yang digunakan oleh peneliti di tuangkan melalui bentuk cerita detail sesuai bahasa, pengetahuan, dan pandangan partisipan berdasarkan pengalamannya.

Data dikumpulkan dengan tehnik wawancara mendalam (in-depth interview), pewawancara memiliki daftar pertanyaan yang disiapkan dan diyakini dapat menjadi semacam format untuk jawaban responden berkaitan dengan proyek peneliti, mencatat jawabannya atau merekamnya dengan alat perekam. Hasil rekaman didengarkan kembali kemudian diketik dan dibuat transkripnya dalam bentuk verbatim (kata demi kata) ditambah dengan catatan lapangan. Analisa data yang akan digunakan pada penelitian adalah teknik Colaizzi. Teknik analisis data Colaizzi akan memformulasikan setiap pernyataan bermkana kedalam kategori dan tema yang selanjutnya akan disajikan dalam bentuk narasi secara lengkap sebagai hasil dari penelitian.

\section{HASIL}

Hasil dari penelitian ini didapat 5 tema besar, yaitu pengetahuan dan pemahaman perawat, bentuk dilema etik yang di alami perawat, bentuk dilema etik yang berkaitan dengan prinsip etik, tindakan saat mengalami dilema etik dan harapan untuk perawat.

\section{Tema 1 : Pengetahuan dan pemahaman}

1. Subtema pertama yaitu mengetahui, subtema ini terbagi menjadi dua kategori antara lain:

a. Kategori memutuskan pilihan, adapun ungkapan beberapa partisipan sebagai berikut:
"Kayaknya ada dua pilihan ya yang harus dipilih ya.." (P.01)

"antara menentukan salah satu $A$ dan $B$ " (P.01)

"aturan yang harus dipilih salah satu sesuai dengan prosedur" (P.01)

"dilema kita inii apa itu yang kita kerjakan.." (P.05)

b. Kategori perasaan bimbang, adapun ungkapan beberapa partisipan sebagai berikut:

"karena ya dilema itu bimbang, kalau dilakukan nggak dilakukan berarti ada imbasnya" (P.01)

"Kalo dari arti bahasa dilema itukan kalo orang jawa itu bilangnya pekewoh jadi rasa tidak enak bingung" (P.02)

"sesuatu yang menurut kita bagus tapi belum menurut orang lain" (P.02)

"permasalahan-permasalahan yang membuat kita bimbang" (P.03)

"tapi sesuai dengan tidak cocok dengan hati nurani kitaa" (P.05)

"dilema itu adalah kegundahan, kebimbangan untuk menentukan suatu keputusan" (P.06)

"terus kalo yang dengan pihak menegemen rumah sakit ya misalnyaa.. ya pandangan saya benar atau enggak, jadi.. misalnya untuk penempatan perawat misalnya disesuaikan dengan jenjang karir" (P.06)

2. Subtema kedua yaitu kurangnya pengetahuan yang terbagi menjadi satu kategori berdasarkan pernyataan partisipan yaitu:

a. Kategori merupakan hal baru, adapun ungkapan partisipan sebagai berikut:

"ya mungkin barang baru ya, kata-kata baru dilema etik itu" (P.01)

"yaapa aku gak bisa jawab, haaa (sambil senyum)" (P.05)

\section{Tema 2 : Bentuk Dilema Etik yang dialami}

1. Subtema pertama yaitu konflik antar PPA, subtema ini terbagi menjadi dua kategori antara lain: 
a. Kategori faktor komunikasi adapun ungkapan beberapa partisipan sebagai berikut:

"miss komunikasi antara pemberi pelayanan dan yang dilayani" (P.01)

b. Kategori faktor kepatuhan perawat adapun ungkapan beberapa partisipan sebagai berikut:

"biasanya hanya kepatuhan fungsi rekam medis aja.." (P.04)

"kita injeksi jam 12.. kita punya buku injeksi.. di buku injeksi di centang.. ternyata di rekam medis tidak dicentang.. akhirnya kan shift yang selanjunya pasti akan complain kok gak di isi.." (P.04)

"disini ada indikator tingkatapa itu.. ketepatan dalam pemberian ee rekam medik kepada rekam medik garis skor itu.. kendalanya disitu kan ada macam-macam PPA, dokter perawat, farmasi,gizi kan gitu..perawat sudah ngisi, gizi sudah ngisi, laborat sudah ngisi ehh farmasi sudah ngisi, tapi kadang terkendala masalah satu CPPT dokter belum terisi.. Jadi makanya terhambatnya itu" (P.05)

2. Subtema kedua yaitu konflik dengan pasien, subtema ini terbagi menjadi dua kategori antara lain:

a. Kategori masalah biaya, adapun ungkapan beberapa partisipan sebagai berikut:

"jadi missnya masalah biaya" (P.01)

"kadang keluarga merasa saya sudah bayar.. kemudian haknya itu di kelas 2 sedangkan dia mintanya di paviliunn" (P.03)

"selama dikeperawatan itu ada pembengkakan biaya.. biaya lebih dari $A$ itu itu yang bikin dilema.. sementara pasien mengotot ke yang harga sudah di setujui sama dokter" (P.01)

b. Kategori masalah kepatuhan, adapun ungkapan beberapa partisipan sebagai berikut:

"yaa aturan harus ditegakkan disitu dilarang merokok jelas sudah, tapi didalampun..sering kita juga menemui" (P.01)

"kemoterapi tanggal 7, tapi karena ketidaktahuan pasien atau pasiennya lupa..mereka itu datang tanggla 8. Kan gituu.." (P.05)
Tema 3 : Bentuk dilema etik yang berkaitan dengan prinsip etik

1. Subtema pertama yaitu prinsip autonomy, subtema ini terbagi menjadi satu kategori antara lain:

a. Kategori meminta persetujuan, adapun ungkapan beberapa partisipan sebagai berikut:

"yang penting dari pihak keluarga mau bertanda tangan tangan dengan resiko apapun" (P.01)

"semuakan tertuju pada pasien jika sudah mengatakan seperti itu, hitam diatas putih yang menang..sudah tanda tangan penolakan ya sudah.." (P.02)

"Saya pun kadang istilahnya bukan.. apayaa.. kesenengen membuka aurot kemudian seperti itu.. tetapi karena kebaikan yasudah saya lakukan. cuman kadang kalok tidak mau.. yasudah kita pasrah.. kita apanamanya otomatis mengajukan surat tanda tangan apa namanya surat penolakan tindakan.." (P.02)

"kalo misalkan kita sudah edukasi tapi tetap tidak bisa.. kita kasih jalan tengahnya dulu gimana kalo memang dia tetap tidak mau.. artinya dia menolak.. serta merta kan harus tanda tangan." (P.04)

2. Subtema kedua yaitu prinsip non maleficience, subtema ini terbagi menjadi dua kategori antara lain:

a. Kategori meminimalisir resiko, adapun ungkapan beberapa partisipan sebagai berikut:

"mau beresiko dengan diselang nanti ada apaapa jatuh dijalan kan jadi masalah" (P.01)

"kita saat mengalami dilema melihat mana yang beresiko paling sedikit pada pasien baru kita ambil keputusan" (P.05)

b. Kategori memberikan tindakan sesuai SOP, adapun ungkapan beberapa partisipan sebagai berikut:

“jadii artinya kalau kita tidak melakukan SOP dengan benar. khawatirnya resikonya juga banyak.. terutama resiko ke pasien" (P.04)

"jadi kita mengurangi kesalahan-kesalahan 
itu.. dengan bagaimana? Dengan bekerja secara profesional sesuai dengan SPO yang berlaku" (P.03)

3. Subtema ketiga yaitu prinsip justice, subtema ini terbagi menjadi satu kategori antara lain:

a. Kategori tidak membeda-bedakan, adapun ungkapan beberapa partisipan sebagai berikut:

"kalaupun toh ini terpaksa, pasien itu kita kasih tindakan dengan duduk walaupun kita dilema, kan gitu yaa.. seharusnya pasiennya kan tidur, mereka kok di anak tirikan.. kan gitu dilemanya kan disitu" (P.05)

4. Subtema keempatyaitu prinsip Veracity, subtema ini terbagi menjadi satu kategori antara lain:

a. Kategori mengatakan sesuai fakta, adapun ungkapan beberapa partisipan sebagai berikut:

"dilema kita tunjukkan setelah kemo efek sampingnya begini nanti pasiennya gak mau kemo, kan begitu" (P.05)

"dari situ kita mengalami dilema karena bagaimanapun diagnosa dari pasien juga harus disampaikan" (P.06)

\section{Tema 4: tindakan yang dilakukan saat mengalami dilema etik}

1. Subtema pertama yaitu secara mandiri, subtema ini terbagi menjadi satu kategori antara lain:

a. Kategori diselesaikan sendiri, adapun ungkapan beberapa partisipan sebagai berikut:

"pertama kali saya lakukan kalo langsung ke klien yang jelas langsung ngomong ngobrol" (P.01)

"kalau saya bisa mengatasi secara intern. saya atasi dulu" (P.03)

"selama kita masih bisa mengatasi sendiri kita atasi sendiri" (P.05)

2. Subtema kedua yaitu koordinasi, subtema ini terbagi menjadi dua kategori antara lain:

a. Kategori secara kebersamaan, Adapun ungkapan beberapa partisipan sebagai berikut: "kita pasti ada temen untuk ee diajak sharring.. la sharring.. kalau bisa diselesaikan dengan teman sharring" (P.01)

"permasalahan-permasalahan yang membuat kita bimbang itu yang kita hadapi ya kita harus diselesaikan bersama" (P.03)

"ya koordinasi kita dapat masalah seperti iniini.. kalo menurut saya seperti ini.. ohh endak pak.. harus gini-gini.. kita kan mengambil suara terbanyak yang rasional" (P.04)

b. Kategori kekompakan, adapun ungkapan beberapa partisipan sebagai berikut:

"kalo disisi yang saya maksut tadi tu bisa terjalin tim kerja yang solid" (P.03)

"ya jelas.. bantuan dari rekan kerja karena kita selalu koordinasi.. gak bisa kita mamutuskan sendiri.." (P.04)

"yaa untukpenatalaksanaan langkahyang kita ambil yaa yang pertama kita mengumpulkan datanya laporan dari perawat pelaksana dan perawat katim kalo ada masalah ini ituu.." (P.05)

c. ketiga meminta bantuan atasan adapun ungkapan beberapa partisipan sebagai berikut:

"kalo masih buntu kita laporan ke karu..terus karu masih buntuu kita sudah punya komite complain unit complain itu sudah punya" (P.01)

“jikaa supervisi ini tidak mampu mengatasi.. baru nanti naik ke.. kita punya namanya itu team complain..gitu.. team complain disini tidak hanya mengatasi masalah apayaa.. complain ketidak puasan.." (P.02)

"kita koordinasikan dengan keinstal warnap. diatasnya saya." (P.04)

"tapi kalau saya tidak bisa mengatasi permasalahan saya akan naikkan ke atas..ke pimpinan saya..ke instal warnap dulu gitu.." (P.03)

\section{Tema 5 : Harapan untuk perawat}

a. Kategori penambahan pengetahuan, Adapun ungkapan beberapa partisipan sebagai berikut: 
"itu kemampuannya SDMnya ditingkatkan" (P.01)

"tiap personal pemberi pelayanan itu harus menguasai apaa.. emm apaa..komunikasi efektif..terutama yaa" (P.01)

"selain ilmu dan teori.. kita perawat.. kita profesi.. kita punya dasar ilmu..gunakan secara bijak kemudian selalu landasi dengan iman dan ilmu" (P.02)

"kita harus selalu belajar ya meningkatkan pengetahuan" (P.05)

"harus tetep seorang perawat harus update ilmu" (P.06)

b. Kategori pelatihan, adapun ungkapan beberapa partisipan sebagai berikut:

"Jadi dari seminar atau itu kita dapat sertifikat." (P.01)

"kita perlu uptodate pelatihan dan diberikan pelatihan.." (P.04)

"tapi selama ini masih belum ada pelatihanpelatihan workshop-workshop" (P.05)

\section{PEMBAHASAN}

\section{Tema 1: Pengetahuan dan Pemahaman}

Pada penelitian ini didapatkan persepsi perawat dilihat dari pengetahuan perawat DKT Jember mengenai pengertian dilema etik sendiri ada yang mengetahui dan tidak mengetahui, satu perawat menyebutkan bahwa kata dilema etik merupakan hal baru dan sangat jarang di dengar sehingga mereka mengalami kesulitan dalam membedakan antara dilema etik atau bukan yang mereka alami dan dalam menentukan suatu keputusan yang harus di ambil serta satu perawat yang mengatakan tidak bisa menjawab, lima perawat menafsirkan dilema etik itu sendiri merupakan suatu pilihan yang harus dipilih dan yang menimbulkan rasa bimbang.

Notoatmodjo dalam Paryanti dkk., 2007 menyebutkan bahwa pengetahuan merupakan domain yang sangat penting untuk terbentuknya tindakan seseorang. Pengetahuan diperlukan sebagai dorongan untuk menumbuhkan kepercayaan diri maupun dorongan sikap, perilaku dan persepsi sehingga dapat dikatakan bahwa pengetahuan merupakan stimuli terhadap tindakan seseorang.
Penelitian saat ini didukung oleh penelitian sebelumnya yang di lakukan oleh Pangaribuan, 2016 dimana disebutkan bahwa faktor-faktor yang mempengaruhi persepsi adalah faktor intrinsik dan ekstrinsik seseorang (cara hidup, cara berfikir, kesiapaan mental, kebutuhan, wawasan dan pengetahuan), dari hal tersebut peneliti berasumsi bahwa persepsi perawat dipengaruhi oleh faktor ekstrinsik berupa pengetahuan perawat mengenai pengertian dari dilema etik itu sendiri.

Tema 2: Bentuk dilema etik yang dialami

Perawat di ruang rawat inap RS.DKT mengalami beberapa dilema etik yaitu ketika berhubungan dengan profesi pemberi asuhan (PPA) dan juga ketika berhubungan dengan pasien saat pemberian pelayanan seperti adanya miss komunikasi antara perawat dengan PPA, masalah ketidak patuhan pengisian rekam medik antar PPA, kepatuhan pasien dan juga masalah pembiayaan pasien yang sering menyebabkan dilema etik pada perawat diruang rawat inap, beberapa perawat juga masih ada yang belum bisa membedakan antara dilema etik atau konflik biasa yang dialami pada saat pemberian pelayanan.

Hasil penelitian saat ini sejalan dengan hasil penelitian sebelumnya yang dilakukan oleh Pujiastuti \& Rr.Sri Endang, 2010 dimana dilema etik yang dialami perawat yaitu ketika memberikan pelayanan yang berhubungan dengan pasien dan saat berhubungan dengan dokter. Isu-isu yang sering muncul dan menyebabkan dilema etik adalah isu-isu mengenai martabat pasien yang berhubungan dengan pasien atau keluarganya serta isu terkait manajemen mengenai masalah dengan pendidikan dan pelatihan ataupun sumber daya yang tidak mencukupi, sikap kerja staf, budaya dan hubungan dengan dokter (Ito dan Natsume, 2015), dari hal tersebut peneliti berasumsi bahwa dilema etik yang dialami perawat yaitu saat berhubungan dengan pasien dan PPA.

\section{Tema 3: Dilema etik yang berkaitan dengan prinsip etik}

Terdapat 4 prinsip etik yang berkaitan dengan dilema etik yang dialami oleh perawat yaitu yang pertama prinsip autonomy didapatkan perawat selalu menjelaskan dan meminta persetujuan mengenai tindakan apa yang akan dilakukan pada pasien, yang ke dua prinsip non maleficience didapatkan perawat 
meminimalisir resiko ketika melakukan tindakan dan memberikan tindakan sesuai dengan SOP yang berlaku supaya tidak terjadi hal yang tidak di inginkan dan merugikan pasien, yang ke tiga prinsip justice yang didapatkan perawat tidak membeda-bedakan dalam pemberian pelayanan karena tujuan utama daam pemberian pelayanan sekarang adalah patient center care dan yang ke empat prinsip veracity yang didapatkan bahwa perawat mengatakan setiap tindakan atau efek dari tindakan harus di katakan sesuai fakta pada pasien, partisipan juga mengatakan bahwa bagaimanapun diagnosa dari pasien juga harus disampaikan sesuai dengan fakta meskipun sebenarnya hal itu merupakan tugas dokter.

Prinsip etik sangat berperan penting pada pengambilan keputusan yang beresiko dapat menyebabkan dilema etik pada perawat (Barlow, 2017), oleh karena itu perlunya memahami mengenai prinsip-prinsip etis dalam praktik keperawatan yang terdiri dari prinsip otonomi (autonomy), kemanfaatan (beneficience), keadilan (justice), tidak merugikan (non maleficience), kejujuran (veracity), menepati janji (fidelity), karahasiaan (confidentiality), akuntabilitas (accountabiliy) (Dalami dalam Ose 2018).

Hasil penelitian saat ini sesuai dengan penelitian yang dilakukan oleh Purnamasari, 2015 dimana selalu memberikan "informed consent" setiap kali akan melakukan tindakan pemberian imunisasi pada anak, sehingga tidak disoalkan secara hukum. Dari hal diatas peneliti berasumsi penyelesaian dilema etik yang kompleks membutuhkan pemahaman tentang prinsipprinsip etik untuk memandu proses pengambilan keputusan.

\section{Tema 4: Tindakan yang di lakukan saat mengalami dilema etik}

Ketika perawat mengalami dilema etik, partisipan menyatakan bahwa pemecahan masalah awal saat mengalami dilema etik bisa dilakukan secara mandiri, dan melibatkan orang lain dengan melakukan pengkajian hingga evaluasi masalah dilema etik yang dialami hingga perlu kekompakan untuk memutuskan suatu keputusan. Menurut Fatah, 2019 menyebutkan bahwa karakteristik tenaga keperawatan sebagai profesi adalah adanya kemampuan melaksanakan fungsi mandiri dengan adanya kewenangan dan pengetahuan yang melandasi keterampilan untuk menyelesaikan masalah dalam praktik keperawatan.
Penanganan dilema etik juga bisa dilakukan dengan mengembangkan intervensi, memecahkan masalah yang terjadi dan kemudian memasukkan kedalam kerangka kerja yang ada pada lembaga dalam rangkan untuk memperbaiki situasi (Ganz dkk., 2015).

Dari beberapa hal tersebut, peneliti berasumsi bahwa langkah asuhan keperawatan dapat digunakan sebagai penatalaksaan dari dilema etik mulai dari pengkajian masalah yang terjadi, penetapan masalah yang terjadi, intervensi masalah yang terjadi, melakukan implementasi dan sampai pada tahap evaluasi baik dalam menangani masalah sendiri maupun dengan team.

\section{a. Tema 5: Harapan untuk perawat}

Perawat mempersepsikan bahwa pembelajaran berkelanjutan sangat diperlukan pada perawat RS DKT untuk kedepannya, dikarena perawat memerlukan update ilmu atau keterbaruan ilmu yang digunakan untuk mengatasi masalah seperti dilema etik, perlunya penambahan ilmu dengan memberikan pelatihan atau seminar untuk menjadikan kualitas kinerja perawat termasuk dalam pengambilan keputusan saat menghadapi dilema etik menjadi lebih tinggi dan lebih baik lagi dalam pemberian pelayanan.

Hasil penelitian saat ini di dukung oleh penelitian sebelumnya oleh Juliati, 2015 yang memiliki hasil bahawa semakin baik dan seringnya pelatihan berupa upaya-upaya mengenai pengendalian infeksi nosokomial dilaksanakan atau diikuti perawat, maka akan meningkatkan pengetahuan perawat yang akan meningkatkan peran perawat tersebut dalam melaksanakan kinerjanya sehari-hari dengan tetap mempertahankan upaya pengendalian terhadap infeksi nosokomial.

Sesuai dengan pendapat Moekijat dalam Ernawati, 2014, bahwa pelatihan harus bisa membantu pegawai menambah pengetahuannya dalam menjalankan tugasnya serta mampu menimbulkan perubahan sikap, kebiasaan, persepsi maupun informasi dalam tindakan yang akan diterapkan. Berdasarkan interpretasi di atas, peneliti berasumsi bahwa pemberian pelatihan pada perawat dapat mempengaruhi persepsi perawat dalam tindakan yang akan di terapkan atau memberikan keputusan. 


\section{KESIMPULAN}

Kesimpulan dari penelitian ini didapatkan perawat senior mempersepsikan dilema etik adalah suatu pilihan yang harus dipilih dan yang menyebabkan perasaan bimbang, dilema etik yang dialami dari 6 perawat yaitu konflik yang berhubungan dengan PPA (Profesi Pemberi Asuhan) dan pasien mengenai komunikasi, pembiayaan, ketidaktahuan dan kepatuhan serta diperoleh dilema etik yang

\section{DAFTAR PUSTAKA}

Astuti, S. D. N. 2012. Hubungan Beban Kerja Dan Kondisi Penyakit Dengan Stres Kerja Perawat Pelaksana Di Intensive Care Unit (Icu) Rsud Polewali Mandar. Universitas Islam Negeri Alauddin Makassar.

Barlow, N. A. 2017. Nurses Contribution To The Resolution Of Ethical Dilemmas In Context. Nursing Ethics. 2:230-242.

Ernawati, S. U. 2014. Pengaruh Pelatihan Terhadap Kinerja Perawat Dengan Motivasi Sebagai Variabel Moderasi (Studi Pada Rsud Dr. Saiful Anwar Malang). 2(2)

Fatah, A. 2019. Tanggung Jawab Perawat Praktik Mandiri Dalam Pemberian Pengobatan Kepada Pasien. Universitas Lampung.

Ganz, F. D., N. Wagner, Dan O. Toren. 2015. Nurse Middle Manager Ethical Dilemmas And Moral Distress. Nursing Ethics. 22(1):43-51.

Ibrahim Yousif, K. 2018. Perception Of Ethical Principles By Hemodialysis Nurses In Khartoum, Sudan. Nursing \& Healthcare International Journal. 1(2):1-5.

Ito, C. Dan M. Natsume. 2015. Ethical Dilemmas Facing Chief Nurses In Japan. Nursing Ethics. 23(4):432-441.

Juliati. 2015. Hubungan Pelatihan Terhadap Kinerja Perawat Pelaksana Di Rumah Sakit Pertamedika Pangkalan Brandan. Jurnal Kesehatan Surya Nusantara. 2(5):1-13.

Nafi'ah, J. 2018. Hubungan Persepsi Beban Kerja Perawat Dengan Stres Kerja Perawat Dalam Kegiatan Mempertahankan Akreditasi Rumah Sakit Paripurna Di Rumah Sakit Tk. Iii Baladhika Husada Jember. Universitas Jember. berhubungan dengan prinsip etik yang terjadi pada perawat ruang rawat inap RS DKT meliputi 4 prinsip yaitu prinsip autonomy, prinsip non maleficience, prinsip justice, prinsip veracity. Untuk meningkatkan kualitas kinerja dari perawat, diharapkan untuk kedepannya perawat di ruang rawat inap diberikan pelatihan atau pembelajaran mengenai dilema etik yang selama ini belum pernah di dapatkan oleh keenam partisipan.

Oerlemans, A. J. M., N. Van Sluisveld, E. S. J. Van Leeuwen, H. Wollersheim, Dan W. J. M. Dekkers. 2015. Ethical Problems In Intensive Care Unit Admission And Discharge Decisions: A Qualitative Study Among Physicians And Nurses In The Netherlands. 1-10.

Ose, M. I. 2018. Dilema Etik Dalam Merawat Pasien Terlantar Yang Menjelang Ajal Di Igd. Jurnal Pendidikan Keperawatan Indonesia. 3(2):145.

Pangaribuan, R. 2016. Nurse Perceptions Of Principles Of Conduct In The Implementation Of Action In Icu Nursing Home Sick At Putri Hijau Hospital Medan. Jurnal Riset Hesti Medan,. 1(1):37-44.

Pujiastuti Dan Rr.Sri Endang. 2010. Dilema Etik \& Pengambilan Keputusan Etis Dalam Praktik Keperawatan Jiwa. Jakarta: Penerbit Buku Kedokteran.

Purnamasari, I. 2015. Dilema Etik Penolakan Imunisasi, Antara Hak Orang Tua Dan Tanggung Jawab Pemberi Pelayanan Kesehatan. Jurnal Manajemen Keperawatan. 3(1):7-12.

Rainer, J., J. K. Schneider, Dan R. A. Lorenz. 2018. Ethical Dilemmas In Nursing: An Integrative Review. Journal Of Clinical Nursing. 27(19-20):34463461.

Sari, S. P., Asmuji, Dan E. Permatasari. 2016. Hubungan Etik Perawat Pelaksana Dengan Tingkat Kepuasan Pasien Di Ruang Rawat Inap Kelas Iii Rsd Kalisat Jember. Universitas Muhammadiyah Jember.

Tappen, M.R. 2010. Essentials Of Nursing Leadership And Management. Edisi 5. United States of America: F.A Davis Company.

Zubović, S. 2018. Ethical Dilemmas Of Nurses And Physicians In The Primary Health Care Setting. Hospice And Palliative Medicine International Journal. 2(5):280-284. 